\title{
Aplikasi Asap Cair Tempurung Kelapa Rendah Benzo[a] Pyrene untuk Meningkatkan Kualitas Se’i Sapi Bali
}

\author{
L. K. Dheko ${ }^{1, *}$, D. Darmakusuma ${ }^{2}$, P. R. Kale ${ }^{1}$ \\ ${ }^{I}$ Program Studi Ilmu Peternakan, Program Pascasarjana, Universitas Nusa Cendana \\ ${ }^{2}$ Program Studi Kimia, Universitas Nusa Cendana
}

\begin{abstract}
ABSTRAK
Penelitian ini telah dilakukan di Kecamatan Amarasi Kabupaten Kupang untuk mendapatkan asap cair tempurung kelapa, Laboratorium Institut Pertanian Bogor menguji kandungan benzo[a]pirene dan total bakteri pada daging, Laboratorium riset terpadu Undana melakukan destilasi asap cair dan mendapatkan nilai organoleptik dan Laboratorium Politeknik Pertanian Kupang menguji kualitas kimia daging se'i sapi Bali. Penelitian ini di lakukan selama 2 bulan yaitu tanggal 26 April sampai 26 Juni 2016. Penelitian ini bertujuan untuk mengetahui kandungan benzo[a]pirene terendah dalam asap cair tempurung kelapa dengan melakukan beberapa proses destilasi untuk diaplikasikan ke daging se'i sapi Bali. Materi yang digunakan adalah tempurung kelapa sebanyak $20 \mathrm{~kg}$, daging sapi segar sebanyak $5 \mathrm{~kg}$ yang diambil pada bagian otot. Rancangan dasar yang digunakan adalah, rancangan acak lengkap (RAL) dengan 6 perlakuan dan 3 kali ulangan sehingga diperoleh 18 unit percobaan. Analisis data dilakukan dengan analisis non parametrik tes Kruskall Wallis dan analisis dengan metode Analisis of Variance (ANOVA). Apabila terdapat perbedaan antar perlakuan maka dilanjutkan dengan uji Beda Nyata Terkecil (BNT). Hasil penelitian menunjukan: total bakteri yang terdapat dalam daging se'i tidak berbeda nyata $\mathrm{P} \leq 0,05$ dari perlakuan yang menggunakan asap cair terhadap daging se'i tradisional P0. 6,6x106 P1. 6,2x106 P2. 5,4x106 P3. 1,7x106 P4. 4,46x103 P5. 3,0x103 sedangkan pada kualitas kimia daging se'i sapi Bali berpengaruh sangat nyata $\mathrm{P} \leq 0,01$ dari setiap perlakuan. simpulan pada penelitian adalah: semakin banyak presentase asap cair maka jumlah bakteri pada se'i sapi semakin berkurang dan rataan kualitas kimia daging se'i sapi Bali akan semakin meningkat.
\end{abstract}

Kata Kunci: Kata kunci: Asap cair, Benzo[a]pirene, Destilasi, Kualitas Daging se'I, Tempurung kelapa

\section{Application of Liquid Smoke Shell Oil Low Benzo[a] Pyrene to Improve the Quality of Bali Cattle $S e^{\prime} i$}

\section{ABSTRACT}

This research has been conducted in the District Amarasi Kupang district to obtain liquid smoke coconut shell, Bogor Agricultural Institute Laboratory tested compounds benzo[a]pirene.dan total bacteria in meat, an integrated research laboratory distillation liquid smoke Undana perform and get the value of organoleptic and agricultural polytechnic Laboratory Kupang test the chemical quality beef cattle se'i Bali. The research was conducted over 2 months ie April 26 until June 26, 2016. This study aims to determine the content benzo[a]pirene. lowest in liquid smoke coconut shell by doing some distillation processes to be applied to the meat of cattle se'i Bali. The material used is coconut shell as much as $20 \mathrm{~kg}, 5 \mathrm{~kg}$ of fresh beef taken on the part of the muscle. The basic design is used, a completely randomized design (CRD) with 6 treatments and 3 repetitions so obtained 18 experimental units. Data was analyzed using non-parametric analysis of Kruskal Wallis test and analysis methods Analysis of Variance (ANOVA). If there are differences among the treatments then continued by Least Significant Difference (LSD). The results showed: Total Bacteria contained in meat $P \leq 0,05$ se'i not significantly different from the treatment of liquid smoke to the meat using traditional se'i P0. 6,6x106 P1. 6,2x106 P2. 5,4x106 P3. 1,7x106 P4. 4,46x103 P5. 3,0x103 while the chemical quality beef cattle se'i $P \leq 0,01$ Bali very significant effect of each treatment. conclusion on the research is: the more the percentage of liquid smoke, the number of bacteria in the cow se'i diminishing and the average chemical quality beef cattle se'i Bali will increase.

Keywords: Benzo[a]pirene, Coconut shell, Distillation, Liquid smoke, Se'i quality

\section{PENDAHULUAN}

Semakin meningkatnya kesadaran masyarakat akan pentingnya gizi pangan yang dikonsumsi, maka permintaan akan dagingpun semakin meningkat. Daging merupakan bahan pangan sumber protein yang baik bagi manusia dan juga sebagai sumber penyakit jika penanganannya kurang higienis (FAO Food and Nutrition Paper, 1984). Daging memiliki komposisi gizi yang baik untuk manusia dan organisme, maka daging termasuk bahan makanan yang mudah rusak

\footnotetext{
*Penulis Korespondensi: L. K. Dheko

Alamat: Jl. Adisucipto, Kupang, NTT 85001

E-mail: dhekoliberius@gmail.com
}

serta mudah tercemar oleh mikroorganisme perusak (Buckle et al.,1986).

Masalah distribusi daging di negara sedang berkembang di daerah tropis semakin bertambah besar dan semakin jauh jaraknya lokasi antara produsen dan konsumen bisa menyebabkan kerusakan pada daging. Untuk memperpanjang masa penggunaan atau pemanfaatan daging dilakukan metode pengawetan. Pengawetan daging dapat dilakukan dengan suhu yang rendah atau suhu yang tinggi seperti pengeringan atau pengasapan. Daging selain dapat dikonsumsi langsung dengan cara dimasak, digoreng dan dipanggang juga dapat diolah menjadi produk olahan daging yang tidak hanya memberikan nilai tambah tetapi dapat memperpanjang masa simpan (Soeparno, 2005). 
Produk olahan daging sapi yang banyak dihasilkan masyarakat khususnya di Kota Kupang adalah se' $i$ Sapi. Se' $i$ (daging asap lokal) adalah salah satu bentuk olahan daging sapi dengan cara pengasapan. Dalam proses pengolahan $S e$ 'i dilakukan dengan cara daging dibersihkan dari jaringan ikat kemudian diiris memanjang lalu dibumbui dan diperam. Adapun tujuan pengasapan yang dijelaskan Nurwantoro dan Djarijah (1997) adalah untuk memperpanjang waktu penyimpanan serta sebagai pengawet dan meningkatkan cita rasa. Lebih lanjut Malelak (2010), menyatakan bahwa pengolahan daging se' $i$ ini populer karena memiliki kekhasan pada proses pengolahan, bau, warna, rasa dan memiliki daya simpan yang lebih lama dan palatabilitasnya tinggi.

Terkait penggunaan pada industri perkebunan dan industri kayu, asap cair yang digunakan adalah asap cair kelas III yaitu berwarna hitam pekat. Sedangkan untuk industri pangan asap cair yang digunakan yaitu asap cair kelas I yang berwarna bening. Asap cair kelas I adalah hasil destilasi dari asap cair kelas III dimana kandungan ter sangat rendah dan aman untuk dikonsumsi (Darmadji, 2009).

Kandungan-kandungan senyawa asap cair sangat menentukan sifat Organoleptik kualitas produk pengasapan. Berdasarkan uraian diatas maka telah dilakukan penelitian dengan judul "Aplikasi Asap Cair Tempurung Kelapa Rendah Benzo[a]pyrene untuk meningkatkan Kualitas Se'i Sapi Bali”.

\section{MATERI DAN METODE}

Penelitian ini telah dilaksanakan pada April 2016 di Kecamatan Amarasi Timur, Kabupaten Kupang. Asap cair yang diperoleh dibawa ke Laboratorium Riset Terpadu Undana untuk melakukan destilisasi. Hasil destilisasi dikirim ke Laboratorium Institut Pertanian Bogor untuk mengetahui molekul Benzo[a]pyrene yang terendah, kemudian diaplikasikan ke daging $s e^{\prime} i$ dan hasil aplikasi tersebut selanjutnya dibawa ke Laboratorium Institut Pertanian Bogor untuk mengetahui total bakteri. Beberapa sampel dibawa ke Laboratorium Politeknik Pertanian Kupang untuk mengetahui kualitas kimia se'i sapi dan sisanya digunakan untuk uji organoleptik. Bahan yang digunakan dalam penelitian ini adalah $4 \mathrm{~kg}$ daging Sapi Bali yang diambil dari otot-otot bagian paha belakang. Bahan tambahan berupa salpeter $\left(\mathrm{KNO}_{3}\right)$, garam dan asap cair tempurung kelapa yang tingkat kandungan Benzo[a]pyrene rendah.

Metode yang digunakan dalam penelitian ini adalah metode percobaan atau metode eksperimen dengan menggunakan Rancagan Acak Lengkap (RAL) pola searah yang terdiri dari 6 perlakuan dan 3 kali ulangan sehingga diperoleh 18 unit percobaan. Keenam perlakuan tersebut adalah:

- P0 adalah Se'i sapi yang dibuat secara tradisisonal atau tanpa asap cair sebagai perlakuan
- $\quad$ P1: $2 \%$ asap cair dicampur dengan $500 \mathrm{~g}$ daging sapi yang akan dijadikan se'I

- $\quad$ P2: 4\% asap cair dicampur dengan 500 g daging sapi yang akan dijadikan se'I,

- P3: 6\% asap cair dicampur dengan $500 \mathrm{~g}$ daging sapi yang akan dijadikan se'I,

- $\quad$ P4: 8\% asap cair dicampur dengan $500 \mathrm{~g}$ daging sapi yang akan dijadikan se'I, dan

- P5: 10\% asap cair dicampur dengan $500 \mathrm{~g}$ daging sapi yang akan dijadikan se'i.

Asap cair yang digunakan adalah asap cair yang benzo[a]pyrene-nya paling rendah.

\section{HASIL DAN PEMBAHASAN}

Penelitian ini dilakukan dengan menggunakan tempurung kelapa sebanyak $20 \mathrm{~kg}$. Tempurung kelapa dikeringkan lalu dimasukkan ke dalam tangki pirolisis yang telah dihubungkan dengan kondensor dengan temperatur $350^{\circ} \mathrm{C}$ selama $12 \mathrm{jam}$. Hasil kondensasi berupa asap cair ditampung, kemudian didestilasi pada temperatur $120-280^{\circ} \mathrm{C}$ sebayak 3 kali dengan waktu yang sama selama 30 menit. Asap cair yang dihasilkan dari proses tersebut kemudian dianalisis untuk mengetahui kandungan benzo[a]pire yang terendah. Setelah itu, asap cair dengan benzo[a]piren terendah diaplikasikan ke daging se'i lalu diukur total bakteri, nilai organoleptik dan kualitas kimianya.

Dari data hasil pirolisis dan destilasi asap cair tempurung kelapa pada Tabel 1 dapat dijelaskan bahwa semakin banyak proses destilasi pada asap cair yang dilakukan maka zat-zat yang terkandung dalam asap cair akan semakin rendah dan menghasilkan asap cair yang sehat sehingga dapat diaplikasikan ke dalam bahan pangan. Hal ini sesuai dengan pernyataan Girard (1992) bahwa pembentukkan berbagai senyawa selama pembuatan asap cair tergantung dari beberapa hal, seperti temperatur pirolisis, waktu dan kelembaban udara pada proses pembuatan asap cair serta kandungan udara dalam kayu. Dikatakan juga bahwa semua proses yang menyebabkan terpisahnya partikel-partikel besar dari asap cair akan menurunkan kadar benzo[a]pirene. Proses tersebut antara lain adalah pengendapan dan penyaringan. berdasarkan hasil perlakuan tersebut maka penelitian dilakukan dengan menggunakan asap cair tahap ke empat kemudian diaplikasikan pada daging se'i untuk melihat total bakteri, nilai organoleptik dan kualitas kimia dalam daging setelah itu dilakukan perbandingan dengan pembuatan se'i secara tradisional.

\section{Total Bakteri pada Daging $S e^{\prime} i$}

Jumlah suatu jenis bakteri tertentu yang terdapat dalam makanan telah digunakan sebagai indicator yang dapat menunjukan tingkat sanitasi dan kondisi pencemaran terhadap makanan tersebut.kelompok bakteri utama yang biasa digunakan sebagai indikator adalah koliform, Enterococcus dan famili bakteri Enterobacteriaceae. Standar jumlah bakteri per gram 
Tabel 1. Hasil pirolisis dan destilasi asap cair tempurung kelapa

\begin{tabular}{lcccc}
\hline \hline \multicolumn{1}{c}{ Parameter } & $\mathrm{P} 0(\mu \mathrm{g} / \mathrm{L})$ & $\mathrm{P} 1(\mu \mathrm{g} / \mathrm{L})$ & $\mathrm{P} 2(\mu \mathrm{g} / \mathrm{L})$ & $\mathrm{P} 3(\mu \mathrm{g} / \mathrm{L})$ \\
\hline Naphthalene & 395.90 & 279.89 & 157.72 & 77.04 \\
Acenaphthylene & 588.76 & 739.35 & 58.78 & 58.68 \\
Acenaphthene & 17.33 & 33.54 & 50.68 & 19.04 \\
Fluorene & 71.86 & 13.03 & 2.15 & $<10$ \\
Phenanthrene & 24.85 & 14.95 & $<10$ & $<10$ \\
Anthracene & 11.93 & 2.44 & $<0.5$ & $<0.5$ \\
Fluoranthene & 6.14 & $<4$ & $<4$ & $<4$ \\
Pyrene & $<0.7$ & $<0.7$ & $<0.7$ & $<0.7$ \\
Benzo(a)Anthrancene & $<0.25$ & $<0.25$ & $<0.25$ & $<0.25$ \\
Chrysene & $<0.75$ & $<0.75$ & $<0.75$ & $<0.75$ \\
Benzo(b)Fluoranthene & $<0.5$ & $<0.5$ & $<0.5$ & $<0.5$ \\
Benzo(k)Fluoranthene & $<0.5$ & $<0.5$ & $<0.5$ & $<0.5$ \\
Benzo(a)Pyrene & $<0.25$ & $<0.25$ & $<0.25$ & $<0.25$ \\
Dibenzo(a,h)Anthracene & $<1.5$ & $<1.5$ & $<1.5$ & $<1.5$ \\
Benzo(g,h)Perylene & $<1.5$ & $<1.5$ & $<1.5$ & $<1.5$ \\
Indenol(1,2,3-cd)Pyrene & $<1.5$ & $<1.5$ & $<1.5$ & $<1.5$ \\
\hline
\end{tabular}

daging yuang disarankan adalah $<10^{6}$ per gram (Jai, 1986).

Dari hasil analisis total bakteri sesuai tabel di atas dapat dijelaskan bahwa semakin banyak persentase jumlah asap cair maka jumlah bakteri akan semakin berkurang pada se'i sapi Bali dan pada perlakuan yang tidak menggunakan asap cair total bakterinya lebih tinggi 6.6 x 106 dibandingkan dengan

Tabel 2. Uji chi square

\begin{tabular}{lcc}
\hline \hline Perlakuan & Total Plate Count & P \\
\hline Kontrol & $6.6 \times 10^{6}$ & \\
$2 \%$ & $6.2 \times 10^{6}$ & \\
$4 \%$ & $5.4 \times 10^{6}$ & 0,224 \\
$6 \%$ & $1.7 \times 10^{6}$ & \\
$8 \%$ & $4.46 \times 10^{3}$ & \\
$10 \%$ & $3.0 \times 10^{3}$ & \\
\hline
\end{tabular}

Hasil analisis Chi square menunjukkan adanya hubungan peningkatan level asap cair $(\mathrm{P}=0,224>0.05)$ dengan penurunan jumlah TPC

melakukan aplikasi menggunakan asap cair. Sejumlah peneliti melaporkan efek antimikrobia yang spesifik dari asap cair. Olsen (1976) dalam Maga (1987), menunjukkan bahwa sediaan asap cair yang digunakan pada konsentrasi $6,5 \mathrm{~g} / \mathrm{kg}$ dapat memperpanjang faselag Staphylococcus aureus sejumlah $105 \mathrm{CFU} / \mathrm{ml}$ selama 4 hari pada suhu $30^{\circ} \mathrm{C}$. Jika digunakan konsentrasi asap 9,8 $\mathrm{g} / \mathrm{kg}$ dapat memperpanjang faselag menjadi 14 hari. Olsen juga mengevaluasi bahwa pada konsentrasi 3,5g/kg daging dapat memperpanjang fase lag bakteri secara nyata pada daging babi giling. Messina et al. (1988), melaporkan bahwa semua produk asap cair yang diuji efektif dalam menghambat pertumbuhan kultur murni Listeria monocytogenes. Lindner (1991), juga telah meneliti bahwa asap cair dapat menghambat pertumbuhan Listeria monocytogenes yang diinokulasikan pada produk daging.

\section{Pengaruh Perlakuan terhadap Nilai Organoleptik Daging Se'i}

Hasil analisis uji non parametrik (uji Kruskal Wallis) menunjukkan bahwa pengaruh perlakuan 1, 2, $3,4,5$ dan 6 berpengaruh sangat nyata $(\mathrm{P}<0,01)$ terhadap nilai organoleptik (warna, aroma, citarasa dan tekstur). Nilai modus warna, aroma, cita rasa dan tekstur daging se'i sapi dalam penelitian ini disajikan dalam Tabel 3.

Warna daging Se'i. Warna daging merupakan salah satu indikator yang dipakai konsumen dalam menilai kualitas daging mentah maupun produk hasil olahan daging. Warna daging segar merupakan faktor utama yang menentukan warna daging hasil olahan.

Warna merupakan salah satu faktor yang mempengaruhi makanan dilihat secara visual dan akan berpengaruh terhadap selera konsumen (Purwati, 2007). Sifat-sifat produk pangan yang paling menarik perhatian pada konsumen dan paling cepat pula

Tabel 3. Nilai modus organoleptik daging se'i sapi

\begin{tabular}{|c|c|c|c|c|c|c|c|c|c|}
\hline \multirow{2}{*}{ Parameter } & \multicolumn{6}{|c|}{ Perlakuan } & \multirow{2}{*}{$\begin{array}{l}\text { Nilai } \\
\text { Umum } \\
\text { Modus }\end{array}$} & \multirow{2}{*}{ SEM } & \multirow{2}{*}{ P-Value } \\
\hline & $0 \%$ & $2 \%$ & $4 \%$ & $6 \%$ & $8 \%$ & $10 \%$ & & & \\
\hline Warna & 3.00 & 4.00 & 4.00 & 4.00 & 5.00 & 4.00 & 4,00 & 0,06 & $<0,01$ \\
\hline Aroma & 2.00 & 4.00 & 4.00 & 4.00 & 4.00 & 5.00 & 4,00 & 0,08 & $<0,01$ \\
\hline Citarasa & 4.00 & 4.00 & 3.00 & 4.00 & 4.00 & 5.00 & 4,00 & 0,07 & $<0,01$ \\
\hline Tekstur & 2.00 & 3.00 & 3.00 & 4.00 & 4.00 & 4.00 & 3,00 & 0,07 & 0,02 \\
\hline
\end{tabular}


IIII! sangat menarik $\mathbb{N}$ menarik $\equiv$ agak menarik \# tidak menarik $\square$ sangat tidak menarik

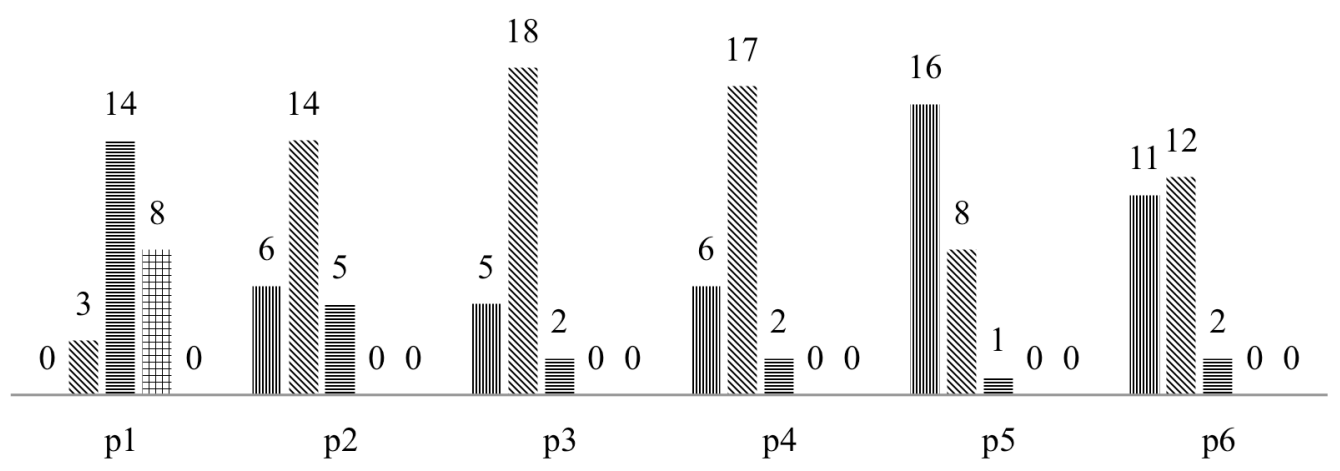

Gambar 1. Grafik warna daging sapi

memberikan kesan disukai atau tidak disukai adalah warna.

Hasil penelitian pada Tabel 3 dan Gambar 1 menunjukan kualitas warna daging se'i sapi Bali yang sangat menarik terdapat pada perlakuan ke-5 dengan tingkat presentase asap cair $8 \%$. Pada perlakuakan ini terdapat perbedaan sangat nyata $(\mathrm{P}<0,01)$ dengan perlakuan $0 \%, 2 \%, 4 \%, 6 \%$ dan $10 \%$ asap cair. Apabila jumlah asap cair yang diberikan kedalam se'i

Tabel 4. Skor uji lanjut Mann-Whitney warna

\begin{tabular}{llllll}
\hline \hline & $0 \%$ & $2 \%$ & $4 \%$ & $6 \%$ & $8 \%$ \\
\hline $2 \%$ & $0,000^{*}$ & - & & & \\
$4 \%$ & $0,000^{*}$ & 0,673 & - & & \\
$6 \%$ & $0,000 *$ & 0,393 & 0,586 & - & \\
$8 \%$ & $0,000^{*}$ & $0,003 *$ & $0,003 *$ & $0,014 *$ & - \\
$10 \%$ & $0,000 *$ & 0,092 & 0,122 & 0,311 & 0,156 \\
\hline
\end{tabular}

sapi Bali sangat sedikit maka tidak akan berpengaruh terhadap warna dari daging se'i sapi Bali dan sebaliknya jumlah asap cair yang diberikan $\mathrm{k}$ edalam daging se'i sapi Bali sangat banyak akan mempengaruhi kualitas warna dari daging se'i tersebut.

Winarni (1998), menyatakan bahwa suatu bahan makanan yang bergizi tinggi dan tekstur yang sangat baik tidak akan menarik selera konsumen untuk dikonsumsi apabila memiliki warna yang tidak menarik atau yang telah menyimpang dari warna sebelumnya. Rataan skor warna daging se' $i$ dan uji lanjut mann-whitneydapat dilihat pada Tabel 4.

Aroma daging se'i. Daging se'i sebagai salah satu oroduk tradisional yang diproses sedemikian rupa agar dapat menghasilkan kualitas daging se' $i$ yang baik. Aroma adah salah satu sifat yang sangat penting dalam menilai kualitas daging se'i oleh konsumen. Aroma juga merupakan salah satu daya tarik bagi konsumen. Aroma daging masak banyak ditentukan oleh metode proses pengolahannya serta pengaruh bahan baku.

Aroma daging se'i sapi yang dihasilkan dari pengaplikasian asap cair tempurung kelapa dapat dijelaskan bahwa aroma sangat menarik pada perlakuan $10 \%$ asap cair dengan jumlah 11 orang, kemudian aroma menarik pada perlakuan $8 \%$ dan $4 \%$ asap cair dengan jumlah 15 orang dan penilaian agak menarik dan tidak menarik pada perlakuan $0 \%$ dengan jumlah 6 orang dan 7 orang (Gambar 2.).

Tekstur daging se'i. Tekstur daging se,i yang sangat lunak pada perlakuan $0 \%$ asap cair dengan jumlah 4 orang panelis, tekstur daging se' $i$ lunak pada perlakuan $0 \%$ dengan jumlah 15 orang panelis, agak keras pada perlakuan $4 \%$ asap cair dengan jumlah 15

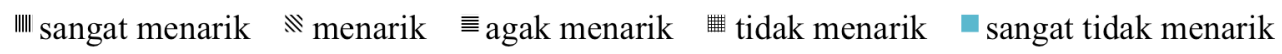

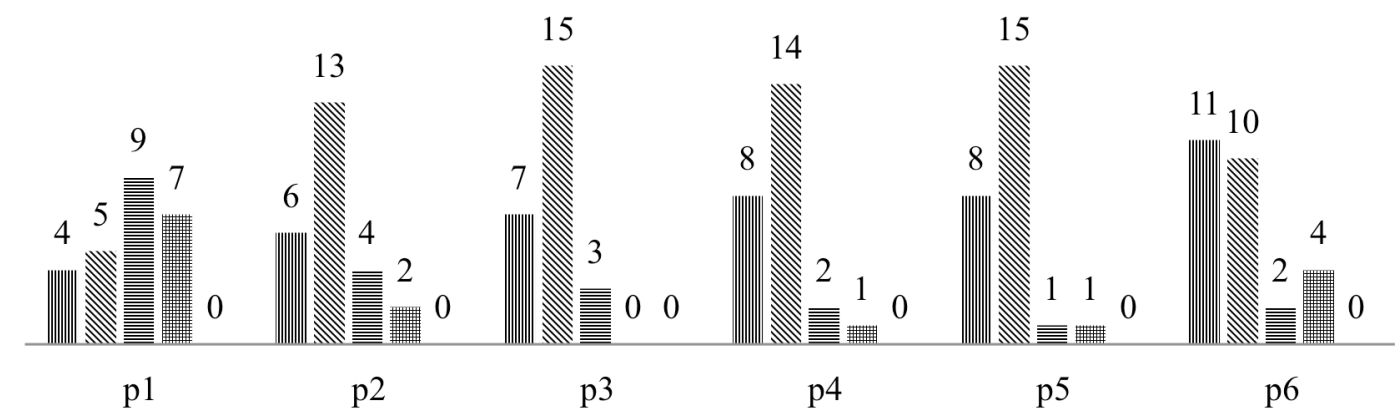

Gambar 2. Grafik aroma daging se' $i$ 


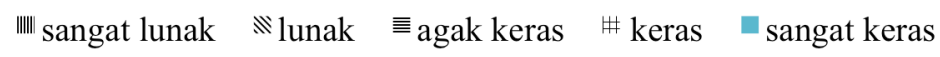

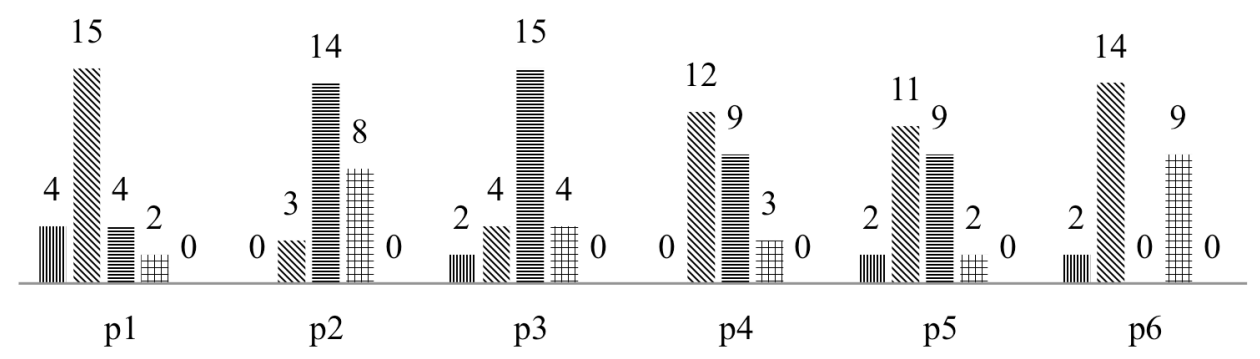

Gambar 3. Grafik tekstur daging $s e^{\prime} i$

orang panelis dan tekstur daging $s e$ ' $i$ yang keras pada perlakuan $10 \%$ asap cair dengan jumlah 9 orang panelis (Gambar 3).

Keempukan dan tekstur daging adalah faktor penentu yang paling penting pada kualitas daging Faktor yang mempengaruhi keempukan daging digolongkan menjadi faktor antemortem seperti genetik, bangsa dan fisiologi, faktor umur, manajemen, jenis kelamin, dan spesies. Faktor postmortem diantaranya meliputi proses chilling, refrigerasi, pelayuan, dan pembekuan termasuk lama dan temperatur penyimpanan, dan metode pengolahan, termasuk metode pemasakan dan penambahan bahan pengempuk.

Cita rasa daging $\boldsymbol{S} \boldsymbol{e}$ ' $\boldsymbol{i}$. Rasa adalah sensasi yang dirasakan dalam lidaseperti asam, asin, manis dan pahit. Pada pengunyahan, serat-serat bahan makanan akan mengeluarkan senyawa-senyawa cita rasa, cairan dan bau ke dalam mulut sehingga menimbulkan rasa suka pada suatu jenis bahan makanan. Cita rasa daging $s e^{\prime} i$ sapi yang diaplikasikan dengan menggunakan asap cair tempurung kelapa yang dirasakan sangat enak pada perlakuan $10 \%$ asap cair, jumlah panelis 12 orang, cita rasa enak pada perlakuan $8 \%$ asap cair dengan jumlah 16 orang panelis, agak enak pada perlakuan $4 \%$ asap cair 14 orang panelis dan cita rasa tidak enak pada perlakuan $0 \%$ asap cair sejumlah 6 orang panelis (Gambar 4.).

\section{Pengaruh Perlakuan terhadap Kualitas Kimia Se'i}

Bahan kering se'i sapi. Hasil analisis menunjukkan bahwa penggunaan asap cair tempurung kelapa berpengaruh sangat nyata $(\mathrm{P}<0,01)$ terhadap kandungan bahan kering se'i sapi. Hasil analisis kandungan bahan kering se'i sapi yang diberikan perlakuan asap cair dapat dilihat pada Tabel 5.

Data pada tabel di atas terlihat bahwa rataan kandungan bahan kering pada daging se'i sapi terendah terdapat pada perlakuan yang diberikan asap cair $10 \%$ yaitu sebesar 57,98\%. Kemudian diikuti perlakuan yang diberi asap cair dengan level $2 \%, 8 \%, 0 \%, 6 \%$ dan yang tertinggi pada level $4 \%$. Hasil analisis uji lanjut menunjukkan bahwa antara perlakuan yang satu dengan perlakuan yang lain berbeda sangat nyata $(\mathrm{P}<0,01)$.

Kandungan air se'i sapi. Hasil analisis menunjukkan bahwa penggunaan asap cair tempurung kelapa berpengaruh sangat nyata $(\mathrm{P}<0,01)$ terhadap kandungan air se' $i$ sapi. Rata-rata hasil analisis total kandungan air se' $i$ sapi dapat dilihat pada Tabel 5. Data pada Tabel 5 terlihat bahwa rataan kandungan air terendah adalah pada perlakuan yang diberikan asap

IIIII sangat enak Nㅗenak $\equiv$

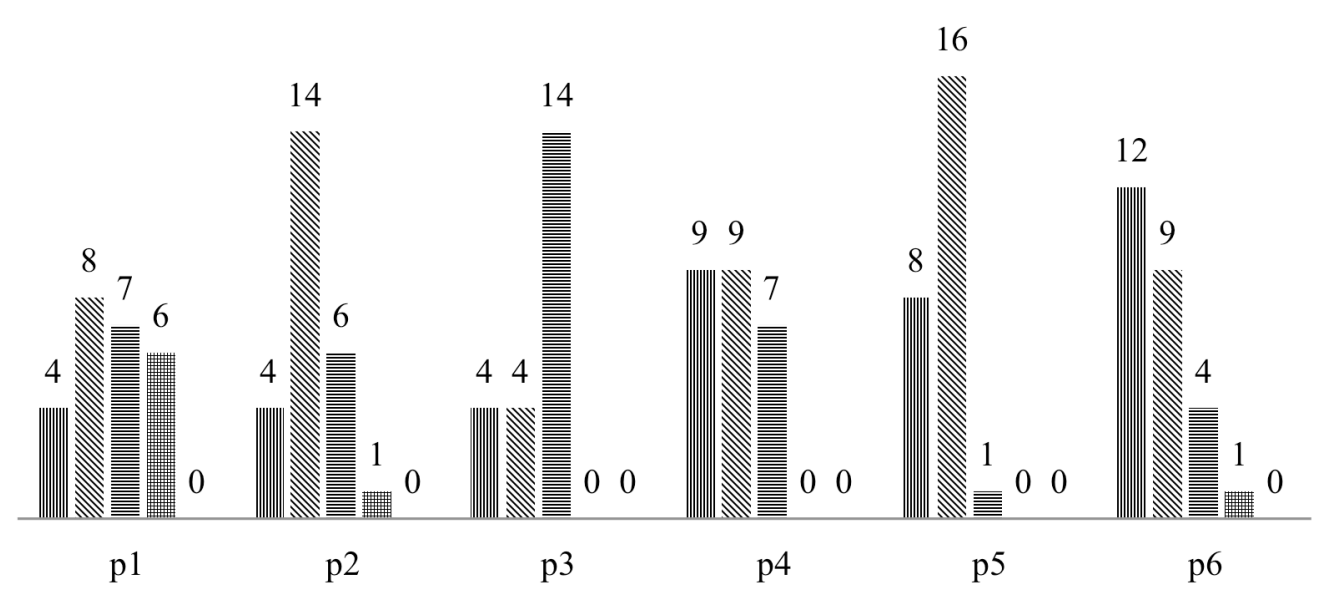

Gambar 4. Grafik cita rasa daging $s e^{\prime} i$ 
Tabel 5. Rataan kualitas kimia daging se'i sapi

\begin{tabular}{|c|c|c|c|c|c|c|c|c|}
\hline \multirow{2}{*}{ Parameter } & \multicolumn{6}{|c|}{ Perlakuan } & \multirow{2}{*}{ SEM } & \multirow{2}{*}{$\mathrm{P}$} \\
\hline & Kontrol & $2 \%$ & $4 \%$ & $6 \%$ & $8 \%$ & $10 \%$ & & \\
\hline Bahan kering & $67.61^{\mathrm{a}}$ & $62.37^{b}$ & $71.26^{\mathrm{a}}$ & $68.71^{\mathrm{a}}$ & $63.57^{\mathrm{a}, \mathrm{b}}$ & $57.98^{b, c}$ & 0.58 & $<0,01$ \\
\hline Protein kasar & 56.11 & 49.49 & 56.85 & 56.71 & 57.46 & 59.61 & 0.45 & $<0,01$ \\
\hline Lemak kasar & 1.45 & 1.72 & 2.18 & 1.94 & 1.61 & 1.76 & 0.11 & 0,50 \\
\hline Kadar air & 32.39 & 37.63 & 28.74 & 31.29 & 36.43 & 42.02 & 0.58 & $<0,01$ \\
\hline $\mathrm{Abu}$ & 8.65 & 6.17 & 8.28 & 8.03 & 7.05 & 5.97 & 0.23 & 0,03 \\
\hline
\end{tabular}

Keterangan: Superskrip huruf kecil yang berbeda pada bari yang sama menunjukan berpengaruh sangat nyata (P<0,01); SEM: Standar Error of mean; dan P: Probobilitas.

cair sebesar $4 \%=28,73 \%$ kemudian diikuti perlakuan yang diberikan asap cair $6 \%=31,28$; tanpa asap cair $=32,38 \%$; level asap cair $8 \%=36,42$; level asap cair $2 \%=37,63$ dan level kandungan air tertinggi pada level asap cair $10 \%=42,02$. Hasil uji lanjut menunjukkan bahwa antar perlakuan berbeda nyata $(\mathrm{P}<0,05)$.

Kandungan protein se'i sapi. Hasil analisis menunjukan bahwa penggunaan asap cair tempurung kelapa berpengaruh sangat nyata $(\mathrm{P}<0,01)$ terhadap kandungan protein $s e^{\prime} i$ sapi. Rata-rata hasil analisis total kandungan protein $s e^{\prime} i$ sapi dapat dilihat pada Tabel 5.

Data pada Tabel 5 terlihat bahwa nilai rataan kandungan protein tertinggi adalah padaperlakuan yang diberikan asap cair $10 \%$ dengan rataan $59,61 \%$ kemudian diikuti perlakuan yang diberikan asap cair $8 \%=57,46$; level asap cair $6 \%=56,71$; level asap cair $4 \%=56,85$; level asap cair $0 \% 56,11$ dan level protein terendah pada level asap cair $2 \%=49,49$. Hasil uji lanjut menunjukkan bahwa perlakuan tanpa pemberian asap cair berbeda sangat nyata dengan perlakuan yang diberi asap cair.

Variasi rataan kandungan protein menunjukkan bahwa pemberian asap cair tempurung kelapa mampu meningkatkan kandungan protein se' $i$ sapi. Pemberian asap cair yang terbaik dalam meningkatkan kandungan protein $s e^{\prime} i$ sapi adalah pada level $10 \%$ bila dibandingkan dengan perlakuan tanpa asap cair.

Semakin tinggi level pemberian asap cair kandungan protein semakin tinggi. Salah satu senyawa dalam asap cair yaitu senyawa fenol dan asam-asam organik yang berfungsi sebagai anti bakteri sehingga menghalangi bakteri-bakteri patogen (colifrom, E.Colli dan Salmonela) yang menghidrolisis asamasam amino selama proses pemeraman.

Lemak kasar Se'i Sapi. Hasil analisis menunjukkan bahwa penggunaan asap cair tempurung kelapa berpengaruh sangat nyata $(\mathrm{P}<0,01)$ terhadap kandungan lemak $s e^{\prime} i$ sapi. Rata-rata hasil analisis total kandungan lemak $s e^{\prime} i$ sapi dapat dilihat pada Tabel 5.

Data di atas terlihat bahwa ratan kandungan lemak terendah adalah pada perlakuan yang tanpa diberikan asap cair sebesar 1,44\% kemudian diikuti perlakuan yang diberikan asap cair $8 \%=1,61$; level asap cair $2 \%=1,72$; level asap cair $10 \%=1,76$; level asap cair $6 \%=1,94$ dan level protein tertinggi pada level asap cair $4 \%=2,18$. Hasil uji lanjut menunjukkan bahwa antar perlakuan berbeda sangat nyata $(\mathrm{P}<0,01)$ kecuali P0 dan P2, P1 dan P2, P2 dan P3, P2 dan P4, $\mathrm{P} 2$ dan $\mathrm{P} 5$ berbeda sangat nyata $(\mathrm{P}>0,01)$. Meningkatnya kandungan lemak diduga karena adanya pengaruh salah satu senyawa dalam asap cair yaitu senyawa fenol. Senyawa fenol diduga menghambat reaksi-reaksi kimia yang negatif pada lemak $s e^{\prime} i$ sapi yang diberi perlakuan asap cair sehingga kandungan lemak se' $i$ sapi pada perlakuan yang diberi asap cair lebih tinggi daripada perlakuan yang diberi tanpa asap cair. Hal ini sejalan dengan pendapat Soeparno (2009), bahwa senyawa fenol dalam asap mempunyai aktifitas sebagai antioksidan yang menghambat ransiditas oksidatif. Lebih lanjut Sudarmadji et al. (1989) menegaskan dalam teknologi makanan, lemak dan minyak memegang peranan yang penting. Lemak dan minyak memberikan rasa gurih yang spesifik yang berbeda dari gurihnya protein, selain juga memberi aroma yang spesifik. Di dalam dunia teknologi pangan seperti roti, lemak dan minyak penting dalam memberikan konsistensi empuk, halus dan berlapis-lapis.

Kandungan abu se'i Sapi. Hasil analisis menunjukkan bahwa penggunaan asap cair tempurung kelapa berpengaruh sangat nyata $(\mathrm{P}<0,01)$ terhadap kandungan abu se' $i$ sapi. Rata-rata hasil analisis total kandungan abu se' $i$ sapi dapat dilihat pada Tabel 5.

Data pada Tabel 5 terlihat bahwa rataan kandungan abu pada daging $s e$ ' $i$ sapi tertinggi terdapat pada perlakuan yang tanpa diberikan asap cair sebesar $8,65 \%$ diikuti perlakuan yang diberi asap cair dengan level $4 \%, 6 \%, 8 \%, 2 \%$ dan yang terendah pada level $10 \%$. Hasil analisis uji lanjut menunjukkan bahwa antara perlakuan yang satu dengan perlakuan yang lain berbeda sangat nyata $(\mathrm{P}<0,01)$.

\section{KESIMPULAN}

Berdasarkan hasil penelitian yang dilakukan dapat ditarik kesimpulan yaitu 1) Asap cair tempurung kelapa yang memiliki jumlah kandungan terendah terdapat pada proses destilasi ke tiga (perlakuan ke empat), dengan jumlah, Naphthalene 77,04 $\mu \mathrm{g} / \mathrm{L}$

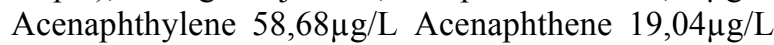
Fluorene $<10 \mu \mathrm{g} / \mathrm{L}$ Phenathere $<10 \mu \mathrm{g} / \mathrm{L}$ Anthracene $<0,5 \mu \mathrm{g} / \mathrm{L}$ dan Fiuoranthene $<4 \mu \mathrm{g} / \mathrm{L}, 2)$ Jumlah total bakteri se' $i$ sapi Bali yang dilakukan aplikasi menggunakan asap cair tempurung kelapa terrendah terdapat pada perlakuan ke lima dengan jumlah asap 
cair $10 \%$, total bakteri $3.0 \times 10^{3}$ di bandingkan dengan menggunakan asap cair $8 \%, 6 \%, 4 \%, 2 \%$ dan secara tradisional total bakteri mencapai $6.6 \times 10^{6}$ keterangan ini bisa dikatakan bahwa semakin banyak presentase asap cair maka jumlah bakteri pada $s e$ ' $i$ sapi semakin berkurang menyebabkan daya simpan daging se'i tersebut semakin lama, 3) Nilai modus organoleptik daging se'i untuk Warna: Dengan penambahan asap cair 8 sampai $10 \%$ sangat mempengaruhi kualitas warna pada daging se'i sapi Bali dengan jumlah $64 \%$ dari 25 Orang Panelis. Aroma: Penambahan asap cair $10 \%$ dapat mempengaruhi tingkat kesukaan lebih tinggi pada daging se'i dengan jumlah 44\% dari 25 Orang Panelis. Cita rasa: Cita rasa yang menunjukan sangat enak pada penambahan asap cair $10 \%$ pada daging dengan jumlah $48 \%$ dari 25 Orang Panelis. Sedangkan untuk tekstur daging se'i sapi Bali yang tampah penambahan asap cair sangat lunak dibandingkan dengan penambahan asap cair. Presentase kesukaan nya $60 \%$ dari 25 Orang Panelis, 4) Rataan kualitas kimia dalam daging yang dilakukan aplikasi manggunakan asap cair tempurung kelapa. (1). Bahan kering yang terrendah terdapat pada perlakuan $10 \%$ asap cair $57,98 \%$ dan yang terrendah pada daging se'i tradisional 67,61\%. (2). Lemak, perlakuan yang menggunakan asap cair $10 \%=1,76 \%$ lebih tinggi dibandingkan dengan yang tradisional 1,44\%. (3). Protein pada perlakuan 10 mempunyai jumlah presentase yang tertinggi 59,61\% sedangkan yang terendah pada perlakuan tradisional $56,11 \%$. (4). Abu pada daging se'i yang tradisional lebih tinggi $8,65 \%$ dibandingkan dengan penggunaan asap cair $10 \%=5,97 \%$. (5). Kandungan air yang tertinggi pada penggunaan asap cair $10 \%=42,02 \%$ sedangkan yang terendah pada perlakuan yang tradisional 32,38 .

\section{DAFTAR PUSTAKA}

Astuti. 2000. Guru dalam proses belajar mengajar. Bandung Sinar Baru. Algesindo.

Ardianto, E. 2014. Komunikasi Massa. Bandung: Simbiosa Rekatama Media.

Bogor Agricultural University. 2008. IPB Kaji Asap Cair Tempurung kelapa sebagai Disinfektan dan Pengganti Formalin. http://www.ipb.ac.id. Diakses tanggal 21 Maret 2015.

Buckle, K. A. 1985. Ilmu Pangan. Penerjemah Hari Purnomo, Adiono, Universitas Iindonesia Press, Jakarta.

Buckle, K. A. 1987. Ilmu Pangan. Universitas Indonesia Press. Jakarta.

Darmadji, P. 2009. Teknologi Asap cair dan Aplikasinya pada Pangan dan Hasil Pertanian. Universitas Gadjah Mada, Yogyakarta.

Desrosier, N. W. and D. K. Tressler. 1977. Fundamentals of Food Freezing. The AVI Publishing Company Inc., Westport, Connecticut.
Fatimah, F. and S. Gugule. 2009. Penurunan kandungan benzo(a)pirena asap cair hasil pembakaran. Chemistry Progress 2(1): 15-21.

Fitriani, A. 2009. Bakteri di Udara. Personal Communication. Diakses pada 20 Agustus 2009.

Frazier, W. C and D. C. Westhoff. 1988. Food Mikrobiology. Forth Edition. New York: McGraw- Hill.

Freites, M., A. Ribeiro, A. Pnto. 2013. Polycyclic aromatic hydrocarbons may contribute for prostate cancer progression. Journal of Cancer Therapy 4:37-46.

Girard, J. P. 1992. Teknologi of meat and products. J.P. Girard (Ed), Ellis Harwod.

Handayana, S. 2006. Kimia Pemisahan, Rosda, Bandung.

Hendayana, S. 2006. Kimia Pemisahan Metode Kromatografi dan Elektroforesis Modern. Remaja Rosdakarya, Bandung.

Jay, J. M. 1986. Modern Food Microbiology Third Edition. Van Nostrand Reinvold. New York.

Komaria, L., A. Ramdja, dan N. Leonard. 2009. Tinjauan teoritis perencanaan kolom destilasi untuk pra-rencana pabrik skala industri. Jurnal Teknik Kimia 4:16.

Lawrie, R. A. 2003 Ilmu Daging Terjemahan Aminuddin Parakkasi. Universitas Indonesia Press, Jakarta.

Lindner, R. L. 1991. Meat Processing with Listeria monocytogenes Reinoculation Control Stage. United States Patent. (Abstr).

Luditama, C. 2006. Isolasi dan Pemurnian Asap Cair Berbahan Dasar Tempurung dan Sabut Kelapa Secara Pirolisis dan Distilasi. Skripsi Sarjana, Departemen Teknologi Industri Pertanian, Fakultas Teknologi Pertanian, IPB.

Lukman, D. W. 2010. Nilai pH Daging. Bagian Kesehatan Masyarakat Veteriner. Fakultas Kedokteran Hewan Institut Pertanian Bogor.

Malelak, G. E. M. 2010. Se,i (daging asap khas timor). Penerbit Lamalera, Jakarta.

Mais, A. 2008. Utilization of Sweet Potato Starch, Flour and Fibre in Bread and Biscuit, PhyscoChemical and Nutritional Characteristics. (Thesis). Massey University.

Maga. Y. A. 1987. Smoke in Food Processing. CSRC Press. Inc. Boca Raton, Florida.

Messina, M. C., H. A. Ahmad, J. A Marchello, C. P. Gerba and M. W. Paquette. 1988. The effect of liquid smoke on Listeria monocytogenes. Journal of Food Protection. 51 (8) : 629-631.

Nurwantoro dan Djarijah. 1997. Mikrobiologi pangan Hewani-Nabati. Penerbit Kanisius. Yogyakarta.

Murtidjo. 1990. Beternak sapi potong. Kanisius, Yogyakarta.

Palungkun, R. 2001. Aneka Produk Olahan Kelapa, Cetakan ke Sembilan, Penebar Swadaya, Jakarta.

Pardosi, R., F. Diba, M. Dirhamsya, dan H. Oramahi. 2010. Bioaktivitas Asap Cair Kulit Buah Durian 
sebagai Bahan Pengawet Papan Partikel. Universitas Tanjungpura, Pontianak.

Palupi, M. P. E. 1986. Tinjauan Literatur Pengolahan Daging. Pusat Antar Universitas Pangan dan Gizi. Universitas Gadjah Mada. Yogyakarta

Poedjiadi, A. 1994. Dasar-dasar Biokimia. Universitas Indonesia Press, Jakarta.

Rubino. 1998. Efek Curing pada Pembuatan Daging Sei terhadap Aseptabilitas, Komposisi Gizi, Masa Simpan dan Residu Nitrit, Tesis, Program Pasca Sarjana, Universitas Gadjah Mada, Yogyakarta.

Rostinawati, T. 2009. Aktivitas Antibakteri Ekstrak Etanol Bunga Rosella (Hibiscus Sabdariffa L.) Terhadap Escherichia Coli, Salmonella Typhi Dan Staphylococcus Aureus Dengan Metode Difusi Agar. Penelitian Mandiri. Fakultas Farmasi, Universitas Padjajaran.

Santoso, S. 2000. Buku Latihan SPSS Statistik Parametrik. PT. Elex Media Komputindo, Kelompok Gramedia, Jakarta.

Soekarto, S. T. 1981. Penilaian Organoleptik. Pusbangtepa, Institut Pertanian Bogor, Bogor.

Soeparno. 2005. Ilmu dan Teknologi Daging. Gadjah Mada University Press, Yogyakarta.

Soeparno. 2009. Ilmu dan Teknologi Daging. Cetakan V. Gadjah Mada University Perss, Yogyakarta.

Sudarmadji, S. 1989. Analisa Bahan Makanan dan Pertanian. Liberti, Yogyakart.

Sutin. 2008. Pembuatan Asap Cair dari Tempurung dan Sabut Kelapa Secara Pirolisis serta Fraksinasinya dengan Ekstraksi. Skripsi. Fakultas Teknologi Pertanian, Institut Pertanian Bogor. Bogor.

Steel, R. G. D. and J. H. Torrie. 1991. Prinsip dan Prosedur Statistika. PT.Gramedia, Jakarta.

Standar Nasional Indonesia. 2006. Bahan Tambahan Pangan-Persyaratan Perisa dan Penggunaan dalam Produk Pangan. SNI 01-7152-2006. Badan Standarisasi Nasional. ICS 67.220.20

Swastawati, F., T. Surti, T. Agustini, dan P. Riyadi. 2007. Liquid smoke performance of lamtoro wood and corn cob. Journal of Coastal Development. 10 (3) : 189 - 196.

Usmiati, S. 2010. Pengawetan Daging Segar dan Olahan. Artikel. Balai Besar Penelitian dan Pengembangan Pasca Panen Pertanian. Kampus Penelitian Pertanian, Bogor.

Tamalo, D. E. Budi, Wirawan, H. Dwi, A. Tyaswuri, dan A. Asma. 2013. Sifat Termal Karbon Aktif Berbahan Arang Tempurung Kelapa, Universitas Negeri Jakarta, Jakarta.

Verma, S. dan S. Jayakumar. 2012. Impact of Forest Fire on Physical, Chemical and Biological Properties of Soil: A review. Department of Ecology and Environmental Sciences, Pondicherry University.

Viksna dan Morozovs. 2008. Levels of Benzo(a)pyrene (BaP) in Fish, Smoked
According to Different Procedures. LLU Raksti 21(315): 24-29.

Yuliani, H., M. Sahlan, H. Hermansya, dan A. Wijanarko. 2012. Selection and Identification of Polyaromatic Hydrocarbon Degrading Bacteria. World Applied Sciences Journal 20(8): 11331138.

Yulita, E. 2012. Pengaruh Asap Cair Serbuk Kayu Limbah Industri Terhadap Mutu Bokar. Balai Riset dan Standarisasi Industri. Palembang.

Walangare, K. B. A., A. S. M. Lumenta, J. O. Wuwung dan B. A. Sugiarso. 2013. Rancang bangun alat konversi air laut menjadi air minum dengan proses destilasi sederhana menggunakan pemanas elektrik. http://ejournal.unsrat.ac.id [diakses pada 10 juni 2016].

Walangare, K. B. A., A. S. M. Lumenta, J. O. Wuwung dan B. A. Sugiarso, 2013. Rancang bangun alat konversi air laut menjadi air minum dengan proses destilasi sederhana menggunakan pemanas elektrik. Jurnal Teknik Elektro dan Komputer UNSRAT 2(2): 95-115.

Widjaya, M., E. Noor, T. T. Irawadi, dan D. Pari. 2008. Perubahan suhu Pirolisis terhadap Struktur Kimia asap cair dari serbuk gergaji kayu pinus. Jurnal Ilmu dan Teknologo Hasil Hutan 1(2): 7377. 